\title{
A múvi abortusz reprezentációja a magyar online médiában
}

\author{
NAGY BEÁTA MAGDA ${ }^{1}$, HUSZÁR KATALIN², \\ KALÓ ZSUZSA ${ }^{3}$, RIGÓ ADRIEN ${ }^{4}$
}

\begin{abstract}
ABSZTRAKT
Tanulmányunkban a magyar online médiában megjelenő abortusz-reprezentációkat vizsgáljuk a lengyel abortusztörvény vitájának hazai recepciója kapcsán. A kutatás célja az volt, hogy képet alkossunk arról, hogyan tematizálódik a müvi terhességmegszakítás kérdése, milyen fogalmi háló részeként, milyen keretezésben mutatja be azt az online sajtó. Mivel a sajtónyilvánosság alapvetố befolyásolója a közvélemény formálódásának, fontos megvizsgálni azt a diskurzust, amelynek terében az érintettek a müvi abortuszra vonatkozó véleményüket kialakítják, illetve döntésüket meghozzák. A tartalomelemzés során nyolc nagyobb témát azonosítottunk, amelyek keretezésében az abortusz kérdése megjelent, ezek: a múvi abortusz társadalmi/demográfiai témaként való megjelenítése, az abortuszszabályozás és az abortusz attitüdök kérdése, az abortusz mint (testi) önrendelkezés, az abortusz-döntésre, illetve az abortusz okaira és következményeire vonatkozó tartalmak és az abortuszt választó nók leírása. Emellett feltártuk azokat az asszociációkat, amelyek visszatérôen társultak az abortusz kérdésköréhez (elsősorban a halál és az illegalitás, deviancia), valamint a kérdés tematizálásából jellemzően hiányzó tartalmakat is.
\end{abstract}

KULCSSZAVAK: múvi abortusz, reprezentációk, társadalmi diskurzus, abortuszszabályozás

\section{ABSTRACT}

\section{Representations of induced abortion in the Hungarian online media}

This study focuses on how induced abortion is represented in the Hungarian online media in relation to the reception of the public debate on the new Polish abortion law. The study was aimed at revealing the major themes, the embedding conceptual network and the framing of induced abortion in the online press. Since the press is an essential influencing factor of public opinion

\footnotetext{
${ }^{1}$ Eötvös Loránd Tudományegyetem Pszichológiai Intézet, Eötvös Loránd Tudományegyetem Pszichológiai Doktori Iskola, nagybeatamagda@imap.cc.

${ }^{2}$ Eötvös Loránd Tudományegyetem Pszichológiai Intézet, hukatakarl@gmail.com.

${ }^{3}$ Eötvös Loránd Tudományegyetem Pszichológiai Intézet, kalo.zsuzsa@ppk.elte.hu.

${ }^{4}$ Eötvös Loránd Tudományegyetem Pszichológiai Intézet, rigo.adrien@ppk.elte.hu.
} 


\section{KÖZELKÉP - Tanulmányok}

due to its broad publicity, research should focus on the characteristics of the discourse in whose space the concerned individuals form their views and make decisions on abortion. A thematic analysis of relevant press releases revealed eight major themes that framed abortion in a specific manner: thematization of induced abortion as a social/demographic issue; legislative issues of; and attitudes towards, abortion; abortion as an act of (physical) self-determination; contents related to the abortion decision; to its causes and consequences; and depiction of women choosing abortion. Furthermore, the analysis revealed the themes most frequently associated with abortion and potentially related themes typically not associated with it.

KEYWORDS: induced abortion, representations, social discourse, abortion law, abortion attitudes

\section{Bevezetés}

Bár a terhességmegszakítás a legtöbb nyugati országban törvényileg engedélyezett és gyakori orvosi beavatkozásnak számít, az abortusz máig rendkívül megosztó, szenzitív és - elsősorban elvi szinten - vitákat generáló téma. Az anyaságról való önkéntes lemondás tabu, miközben mindig voltak és vannak olyan élethelyzetek, amelyekben a nők a várandósság megszüntetését választják - legális vagy illegális módon, a társadalmi kontextustól függően.

A 2016-os teljes abortusztilalomról szóló lengyel törvénytervezet és a körülötte kialakult politikai és társadalmi vita a hazai médiában is a figyelem előterébe emelte nem csak a lengyel politikai történéseket, de magát a művi abortusz témáját is. A terhességmegszakítások száma és a születésszámhoz viszonyított aránya a kedvező irányú tendenciák ellenére is olyan problématerülete a népesedéspolitikának, amelynek megoldásához interszektoriális együttműködésre, az egészségügyi, szociális és oktatási rendszerek összehangolt feladatkezelésére van szükség. Ez azonban csak egy adott társadalmi kontextusban képzelhető el, ezért elengedhetetlenül fontos mindannak a közös tudásnak, értelmezési rendszernek és reprezentációknak az ismerete, amelyben a társadalom tagjai az adott időszakban osztoznak.

Tanulmányunkban a szakirodalmi háttér felvázolása után egy olyan kutatás eredményeit ismertetjük, amelyben azt vizsgáltuk, hogy milyen diskurzus bontakozik ki az online hírportálokon a múvi abortusszal és annak szabályozásával kapcsolatban, vagyis melyek azok a fogalmi keretek és tudáselemek, amelyek a terhességmegszakítás témájához kapcsolódnak. 


\section{KÖZELKÉP - Tanulmányok}

\section{Elméleti háttér}

\section{A MÛVI ABORTUSZ5 EGÉSZSÉGÜGYI, JOGI ÉS KULTURÁLIS KONTEXTUSBAN}

A terhességmegszakítás különböző formáit világszerte jelentős számban végzik el (a világon évente nagyjából 56 millió a művi abortuszok száma), így az a leggyakoribb nőgyógyászati beavatkozásnak számít, ám az összes abortusz 45\%-át a nem biztonságos művi vetélések adják (Ganatra et al. 2017). 1990 és 2014 között a világ fejlett országaiban 41\%-kal csökkent a terhességmegszakítások száma (a legnagyobb arányban a kelet-európai államokban), a fejlődő országokban viszont a vizsgált 25 év során lényegileg nem változott a gyakoriság (Sedgh et al. 2016). A művi abortuszok száma Magyarországon is közel két évtizede csökkenő tendenciát mutat. 2018ban a megszakíttatott várandósságok száma 26,9 ezer volt, ami az előző évi adatokhoz képest 5,6\%-os csökkenést, a '90-es évek mutatóihoz képest kevesebb, mint egyharmados gyakoriságot jelent, a befejezett terhességek számához viszonyítva azonban még mindig nagyjából minden három élveszületésre jut egy művi abortusz (Központi Statisztikai Hivatal [KSH] 2019).

A művi abortuszhoz való törvényi hozzáférhetőség az egyes államokban nagyon különböző, a törvényi szabályozás általában időbeli és/vagy indikációs korlátozást jelent. A nők 25\%-a él olyan országban, ahol a terhesség művi megszakítása szigorú szabályozás alá esik, vagy nagyjából tiltott (Marecek - Macleod - Hoggart 2017). Az Egészségügyi Világszervezet (WHO) felmérése szerint az illegális és nem biztonságos abortuszok legnagyobb részét a szigorúbb szabályozású fejlődő országokban hajtják végre, ez az összes művi vetélés 88\%-át jelenti (Sedgh et al. 2016).

Az abortuszok arányát egy társadalomban számos tényező befolyásolja. Ezek egyike a törvényi szabályozás (jogi környezet), de hatnak rá a gazdasági fejlettség mutatói, az abortuszszolgáltatások elérhetősége és a terhességmegszakítás stigmatizáltságának mértéke is (Ganatra et al. 2017). Az egyes országok között jelentős különbségek vannak a reproduktív egészségre vonatkozó ismeretek, valamint a fogamzásszabályozásban alkalmazható eszközök és szolgáltatások hozzáférhetősége vonatkozásában: a hozzáférhetőség hiánya szignifikánsan magasabb abortusz-rátával jár együtt. Azokban az országokban, ahol az abortuszszabályozás szigorú, jellemzően a fogamzásszabályozás sem megfelelően hozzáférhető (vagy csak egyes csoportok, például a férjezett nők számára elérhető), amely emeli a terhességmegszakítások számát. Az elvégzett abortuszok aránya nem különbözik jelentősen azokban az országokban, ahol az abortusz szigorúan korlátozott, és ott, ahol az abortusz széles körben legális, vagyis annak a valószínűsége, hogy egy nő elveteti a nem kívánt terhességét, nem függ a jogi szabályozástól (Sedgh et al. 2016, World Health Orga-

\footnotetext{
${ }^{5}$ A következőkben abortuszon a terhesség művi megszakítását értjük, kizárva a spontán vetélést és az egészségügyi okokból (pl. magzati rendellenességek) miatt végrehajtott terhességmegszakításokat.
} 


\section{KÖZELKÉP - Tanulmányok}

nization [WHO] 2012). Fontos viszont, hogy a törvényi korlátozás mértéke és a biztonságos abortuszok aránya között negatív irányú az összefüggés (Ganatra et al. 2017).

Sokszor azonban a törvényi szabályozás nincs összhangban az egészségügyi gyakorlattal. Új-Zélandon és Srí Lankán például az abortusz büntethető, ennek ellenére jónak mondható az elérhetősége. Ezzel ellentétben az USA egyes államaiban, bár jogilag lehetséges, a gyakorlatban mégis nehezen hozzáférhető a terhességmegszakítás - például azért, mert az egészségügyi dolgozók elutasítják az abortusz elvégzését, illetve egyes államokban kevés olyan klinika áll rendelkezésre, ahol egyáltalán végeznek ilyen beavatkozást (Marecek et al. 2017). Magyarországon a vallás- és lelkiismereti szabadságból fakadóan a terhességmegszakítás elvégzésére, illetve az abban való közreműködésre - az állapotos nő életét veszélyeztető helyzetek kivételével - orvos és egészségügyi szakdolgozó nem kötelezhető ${ }^{6}$. A szülészeti-nőgyógyászati osztályt működtető állami és önkormányzati intézményekben biztosítani kell legalább egy terhességmegszakítást végző csoport működését. ${ }^{7}$

Az abortusszal összefüggő kulturális normák és értékek szintén világszerte változóak. Fontos szerepe van abban az adott ország vallásosságának, mivel a vallás és az egyház nagy befolyással lehet a lakosság attitűdjeire, az állam politikájára és a jogi szabályozásra is. Bizonyos vallások, például a kereszténység, azon belül is a katolikus egyház, morálisan elítélendőnek tartja a művi abortuszt (Marecek et al. 2017). Ferenc pápa alapvetően továbbra is követi a XX. századi egyházi vezetők abortuszellenes tanítását, habár kiemeli az isten általi megbocsátást az abortuszon átesett nők számára (Tollefsen 2015). Általánosan az látható, hogy a nagy katolikus populációval rendelkező országokban jellemzően szigorúan korlátozó abortuszszabályozás van érvényben (Marecek et al. 2017). Példa lehet erre Lengyelország, ahol jelenleg az 1993-as abortusztörvény hatályos, mely mindössze három esetben teszi lehetővé a terhességmegszakítást: ha a terhesség a várandós nő életét vagy egészségét veszélyezteti, nemi erőszak vagy vérfertőzés, illetve a magzat súlyos vagy visszafordíthatatlan károsodása esetén ${ }^{8}$. A katolikus egyházzal szemben ugyanakkor a dán lutheránus egyház például nem tart fent hivatalos álláspontot az abortusz kérdésében, ami szerepet játszhat az abortusz relatíve nagyobb támogatottságában a dánok körében (Uldall 2015).

Egyéb, a terhességmegszakítás hozzáférhetőségét befolyásoló kulturális tényezők közé tartozik a házasságon kívüli szexuális élet elfogadottsága, a gyermeknemzés és a férfiasság kapcsolata, felelősség a fogamzásgátlásért, az abortusz stigmatizáló jellege, vagy épp a fiúgyerekek preferenciája, ami nemileg szelektív abortuszokhoz vezet Indiában és Kínában (Papworth 2011, Marecek et al. 2017).

\footnotetext{
${ }^{6}$ 1992. évi LXXIX. törvény a magzati élet védelméről, 14. §.

7 1992. évi LXXIX. törvény a magzati élet védelméről, 13. § (2) pont.

${ }^{8}$ https://www.un.org/esa/population/publications/abortion/doc/poland.doc.
} 


\section{KÖZELKÉP - Tanulmányok}

A művi abortusz elfogadhatósága nem független a társadalomban jelen lévő, a nemi szerepekkel kapcsolatos vélekedésektől sem: a liberálisabb nemi szerep attitűdök az abortuszhoz való hozzáférés támogatásának nagyobb mértékével járnak együtt (Beauvais - Mann - Lore 2016). Ehhez hasonlóan általában a feminizmus iránti pozitív érzések is növelik az abortusz támogatottságát, ám ez függ az ország aktuális politikai klímájától is: az USA-ban a tény, hogy a feminista mozgalom a demokraták szövetségese lett, megnehezíti, hogy a választáspárti (pro-choice) attitűdök gyakoribbak legyenek a nem demokrata választóknál is (Beauvais et al. 2016).

Az adott társadalmi-gazdasági és szociokulturális környezet, valamint az aktuális történelmi-politikai kontextus népességszámot formáló hatását példázza a szelektív abortuszok kérdése a Dél-Kaukázus államaiban (Örményország, Azerbajdzsán és Grúzia). A Szovjetunió felbomlása utáni gyors ütemű társadalmi változások, az instabil, akár háború kitörésével fenyegető politikai helyzet, a gazdasági nehézségek, a jelentős mértékű népvándorlás adták azt a történelmi hátteret, amelyen mintegy az új politikai és gazdasági szabadság megtestesüléseként a nemileg szelektív terhességmegszakítás általánosan elérhetővé és széles körben elfogadottá vált. A gazdasági recesszió, a szociális jóléti rendszer lebontása, a közegészségügyi rendszer átalakítása mind csökkentette az egy főre eső jövedelmet és növelte a családok megélhetésének költségét, ami a kívánt családnagyságra vonatkozó elképzeléseket is radikálisan befolyásolta, és felerősítette a fogamzásszabályozás és a művi abortusz iránti keresletet. Mindeközben a fiúgyermekek gazdasági értéke nőtt, mivel a családok megélhetését sokszor a Nyugat-Oroszországban és Szibériában munkát vállaló férfiak biztosították, míg társadalmi szinten a határok megvédése, a katonaság létszámának folyamatos emelése miatt lett fontos a fiúgyermekek számának növekedése. A terhességmegszakítások számának alakulása és a szelektív abortuszok elfogadottsága tehát nem egy társadalom hosszú távú jellemzője, inkább egy adott történelmi helyzetre adott társadalmi-demográfiai válasz (Hohmann - Lefèvre - Garenne 2014).

Láthatjuk tehát, hogy az abortusz melletti döntést a tágabb társadalmi és kulturális kontextus is jelentősen befolyásolja. A terhességmegszakítással kapcsolatban fontos ezért a társadalmi diskurzust is vizsgálni, mivel az abortusszal kapcsolatos döntések a társadalom által közvetített normák és törvények által meghatározott kontextusban születnek.

\section{Abortusszal kapcsolatos attitüdök}

Hagyományosan a művi abortusszal összefüggő attitűdöket két csoportra, választáspárti (pro-choice) és abortuszellenes vagy életpárti (pro-life) viszonyulásra szokás felosztani. A pro-life nézet középpontjában azon meggyőződések állnak, amelyek szerint a magzat emberi lény, a múvi abortusz a gyilkosság morális megfelelője, és 


\section{KÖZELKÉP - Tanulmányok}

csakis Isten hozhat döntést életről és halálról. Ennek megfelelően az élet a fogantatás pillanatában (vagy legkésőbb a terhesség első trimeszterében) kezdődik. Ezzel szemben a pro-choice attitűd szerint az emberi élet a születéssel veszi kezdetét, a magzat az anyához tartozik, mintegy az ő kiterjesztése. A művi abortusz egy nő önmeghatározásához való jogának nélkülözhetetlen eleme, ezért az abortuszról való döntés minden esetben egyénileg mérlegelendő, individuális (Parsons - Richards Kanter 1990). A témában végzett vizsgálatok eredményei szerint azonban az egyén szintjén a terhességmegszakítással kapcsolatos attitűdök általában nem egyszerűsíthetők le igen/nem (elfogad/elutasít, választáspárti/életvédő) dichotómiára. Az egyéneknek a valóságban ennél sokkal árnyaltabb véleményük van, amelynek fontos meghatározói az abortusz indikációja és kontextuális információi is. Az emberek általában elfogadóbbak a terheségmegszakítással kapcsolatban, ha megértik annak okát, vagyis ha a kontextuális információ is jelen van, mert ilyenkor jobban bele tudják képzelni magukat a nő helyzetébe, vagy a körülmények részletei indokot szolgáltatnak a döntéshez (de Crespigny - Wilkinson - Douglas - Textor - Savulescu 2010). Ráadásul a különböző attitűdök akár együttesen is jelen lehetnek - bár a két nézet alapjában véve ellentmondónak tűnik, mégis sokan hisznek az élet szentségében, és az abortusz széles körü szabályozását támogatják, azonban fontos számukra a személyes választás lehetősége is (Bowman - Marsico 2014).

Jozkowski, Crawford és Hunt 2018-as vizsgálatában a résztvevők, miután saját magukat élet-párti és választás-párti kategóriába sorolták, nyílt végű kérdéseket kaptak az abortusz elfogadhatóságára, általában véve (pl. Ön szerint milyen körülmények között kell, hogy a nők hozzáférjenek a biztonságos, törvényes abortuszhoz?; Milyen körülmények között gondolja, hogy a nőknek nem szabad hozzáférniük a biztonságos, törvényes abortuszhoz?). Amint azt a szerzők megjegyzik, ha a prolife és pro-choice attitűd egy homogén vélemény volna, úgy minden válasz a 'semmilyen körülmények között nem tartom elfogadhatónak az abortuszt', illetve a 'minden körülmény között elfogadhatónak gondolom az abortuszt' volna. Az eredmények szerint azonban az önmagukat élet-pártinak vallóknak is csak 22\%-a mondta azt, hogy semmilyen körülmények között nem szabadna a nőknek terhességüket megszakíttatni, és a pro-choice oldalt képviselők közül is csak 1,6\% vélte úgy, hogy minden körülmény esetén hozzá kellene férnie a nőknek az abortuszhoz. A fentiek alapján a szerzők felhívják a figyelmet arra, hogy az élet-párti vagy választás-párti attitűd csak egy címke, amivel az emberek azonosítják magukat, illetve egy ideológiai pozíció, amely valószínűleg nem tükrözi pontosan a legtöbb ember valódi érzéseit, véleményeit vagy hiedelmeit a biztonságos, legális abortusz elérésére vonatkozóan (Jozkowski et al. 2018).

A társadalmi diskurzusban jelen van a "helyes” és a „helytelen” abortusz morális megkülönböztetése, amit a terhességmegszakítás körülményei határoznak meg (Furedi 2001). A társadalmilag elfogadható okok és körülmények között szerepel a magzati rendellenesség, a fiatal életkor vagy ha a terhesség erőszak, vérfertőzés so- 


\section{KÖZELKÉP - Tanulmányok}

rán, illetve gondos védekezés mellett jött létre, és általában az első trimeszteres abortusz. A társadalmilag kevésbé elfogadott, „helytelen” abortuszok azok, amelyeket későbbi gesztációs korban hajtanak végre, amely többedik abortusza a nőnek vagy amely egy fogamzásgátlás nélkül létrejött terhességet szüntet meg. Ezek a morális megkülönböztetések akár a választáspárti-életvédő attitűdöktől függetlenül is jelen lehetnek (Norris et al. 2011). A magzati rendellenességekre visszatérve, ahogy azt Dominique Memmi megjegyzi, ezek között is megkülönböztethetőek az „elégséges” vagy „jó”, illetve a „rossz” indokok a terhesség megszüntetésére. A „jó” indokok közé sorolódnak általában a halállal végződő anomáliák vagy genetikai rendellenességek, csakhogy ezek jelentős része (pl. a súlyos szív- és érrendszeri megbetegedés a magzatnál) szabad szemmel nem látható, így bár orvosilag elfogadható indoka lehet a terhesség művi befejezésének, a szülők nézőpontjából kevésbé megragadható, mint például a végtaghiány vagy a törpeség (Takács 2015a).

\section{A média abortuszreprezentációja}

A tömegmédiának az emberek gondolkodására gyakorolt hatása a 20. század egészében élénken kutatott téma volt, napjainkban, a web2 világában pedig vizsgálata egyre intenzívebb. A tömegmédia jelentősen formálja a közvéleményt, kontextust nyújt annak kibontakozásához, egyúttal hozzájárul annak meghatározásához, hogy mi számít széleskörben „normálisnak és alapvetőnek” (Purcell - Hilton - McDaid 2014). Seale (2003) szerint, ha a betegséggel-egészséggel vagy az egészségüggyel kapcsolatos élményeket szeretnénk megismerni, fontos megvizsgálni, hogy a média milyen történetekről számol be, azokat hogyan tálalja közönségének, valamint az is lényeges, hogy milyen történetekről nem tesz említést, mi az, ami nem része a diskurzusnak. Az, ahogy az egészségügyi témák konstruálódnak (a keretezés és nyelvhasználat által), befolyással bír arra, hogy azok miként interpretálódnak és tapasztalhatók meg a mindennapi életben. A médiában fellelhető történetek, keretezések nemcsak az átlagolvasókra, de az egészségügyi dolgozókra és a törvényhozókra is hatással vannak, sőt magukra a tartalom-előállítókra is visszahathatnak (Seale 2003).

A média abortuszreprezentációinak vizsgálata döntően két paradigmát követ: részben azt vizsgálják, hogy a különböző nyelvezet, például az abortuszellenes szervezetek által használt kifejezések befolyásolhatják-e az emberek attitűdjeit a művi abortusszal kapcsolatban, másrészt pedig az a keret, narratív kontextus képezi a vizsgálat tárgyát, amelyben a múvi abortusz megjelenítődik.

Az abortusszal kapcsolatos diskurzus az életvédő és választáspárti retorika, érvrendszer mentén polarizált (Mikołajczak - Bilewicz 2014), ami leginkább az abortusz alanyát illető szóhasználatban figyelhető meg. Boltanski szerint a magzat nyelvi megjelölése (embrió, baba, gyermek stb.) olyan, önkényesen konstruált kategóriát 


\section{KÖZELKÉP - Tanulmányok}

jelent, amely egyben a róla való gondolkodást, a magzatnak mint társadalmi/biopolitikai alanynak a helyét és helyzetét is meghatározza (Takács 2015b). A terhességmegszakítás kapcsán az életvédő retorikában jellemzően a „meg nem született gyermek”, a választáspártiban „magzat” vagy „embrió” megjelölés használatos. Mikołajczak és Bilewicz (2014) kutatásukban igazolták, hogy a gyermek, illetve a magzat szó használata más pszichológiai kontextust hív elő a befogadóban: terhességmegszakítással kapcsolatos szövegek olvasóinál a magzat szó prezentálása a gyermek szó használatához képest a választott (nem orvosi vagy jogi indikációjú) abortusz kapcsán támogatóbb attitűddel járt együtt. Feltevésük szerint a gyermek szó a magzattal szemben több kognitív hozzáférést nyújt annak emberi mivoltához, tulajdonságaihoz, míg a magzat szóhoz kevesebb emberi tulajdonságot társítunk, így ez egy távolító, dehumanizációs mechanizmusnak tekinthető. Ez a távolságtartás segíthet a nőknek a be nem fejezett terhességgel való megküzdésben, illetve megfontoltabb döntést tesz lehetővé a nem kívánt terhesség esetén. A szerzők szerint a már eleve ambivalens, morálisan eldöntetlen esetekben lehet a nyelvhasználatnak befolyásoló hatása (Mikołajczak - Bilewicz 2014).

A szóhasználaton túl az abortusszal kapcsolatos történetek, narratívák és az aszszociált képzetek is formálják azt, hogy milyen kép alakul ki bennünk a terhességmegszakításról. Sisson és Kimport (2014) az 1916 és 2013 közötti amerikai televíziós műsorok és filmek abortuszhoz kapcsolódó cselekményeit elemezve azt találták, hogy azokban az abortusztörténetek gyakoribbak, mint azt a populáris diskurzus sugallja, mely utóbbi szerint az abortusz még mindig az egyik legerősebb televíziós tabu. Vizsgálatuk eredménye szerint ugyanakkor a terhességek kimenetelének bemutatása összességében nem tükrözi a valós statisztikákat sem. A vizsgált 310 cselekmény 9\%-ában a nők az adoptálást választották, amely mérték a való életben $1 \%$ körüli. A halálesetek meglepően gyakori előfordulását találták a cselekményekben: a történetek 13\%-ában az abortuszhoz folyamodó nő életét vesztette, azokban az esetekben is, amikor végül nem végezték el a terhességmegszakítást. 9\%-uk az abortusz következtében halt meg, amely arány meglehetősen eltúlzott: valójában annak az esélye, hogy a biztonságos abortusz halálhoz vezet, statisztikailag közel nulla (Sisson - Kimport 2014). Későbbi vizsgálatuk (Sisson - Rowland 2017) szerint a filmbéli karakterek 37,5\%-a tapasztalt meg valamilyen komplikációt vagy negatív egészségi következményeket. Ez az érték szintén nem felel meg a valós statisztikáknak, ahol ez az arányszám 2,1\% körüli. Hasonlóan felülreprezentált a múvi vetéléssel öszszekapcsolt meddőség, súlyos mútétek (pl. hysterectomia), mentális problémák és egészségkárosító viselkedések (pl. öngyilkosság, ittas vezetés) előfordulása, valamint az abortusszal összefüggő mortalitás is - utóbbi 7000-szerese a valós statisztikai adatoknak (Sisson - Kimport 2014, Sisson - Rowland 2017). A televízió tehát az orvosi komplikációk és hosszútávú káros következmények felülreprezentálásával, a halállal végződő abortuszok hangsúlyozásával, a terhességmegszakítás és halál, vagy önmagában az abortusz megfontolása és a halál ismételt, narratív összekapcso- 


\section{KÖZELKÉP - Tanulmányok}

lásával drámaian felnagyítja az abortusz egészségi kockázatait, és reprezentációját a veszélyesség irányába tolja el (Sisson - Kimport 2014, Sisson - Rowland 2017).

A művi abortusz médiareprezentációjával foglalkozó tanulmányok külön csoportját képezik azok, amelyek az abortusz stigma megjelenését vizsgálják, elsősorban kvalitatív tartalomelemzéssel. A szerzők szerint az abortuszt választó nők sztereotipizáló ábrázolása, az átlagtól eltérőként bemutatása hamisan távolítja őket a társadalom többi tagjától, ami a stigmatizáció folyamatára jellemző. Hasonlóan erősíti a társadalmi diskurzusban megjelenő megbélyegzést az, ha csak a nőket teszik felelőssé a reproduktív döntésekért, illetve, ha a nők abortusszal kapcsolatos élményeinek összetettségét és változatosságát negálva azt a döntésben szerepet játszó különböző szempontok említése nélkül, leegyszerüsítve jelenítik meg (Purcell et al. 2014).

\section{Kutatási kérdés, módszer, minta}

A következőkben bemutatásra kerülő vizsgálatban a magyar online hírportálok és női magazinok művi abortusszal kapcsolatos cikkeinek szövegét elemeztük. A cikkek kiválasztásához témaként a 2016-os teljes abortusztilalomról szóló lengyel törvénytervezetet és annak visszhangját jelöltük meg.

2016-ban a lengyel kormány egy civil szervezet abortuszszabályozást szigorító javaslatát tárgyalta, amely az abortusz minden formáját tiltotta volna, valamint az ahhoz folyamodó nők és a terhességmegszakítást végző orvosok büntethetőségét is kilátásba helyezte. A törvénytervezetre Lengyelország- és Európa-szerte tüntetésekkel reagáltak. Később a kormány elvetette a szabályozás szigorítását, és továbbra is az 1993-as abortusztörvényt hagyta érvényben. A 2016 tavaszán kezdődő, majd őszszel folytatódó, a lengyel abortuszszabályozást szigorító törvénytervezet elleni tüntetések világszerte, így Magyarországon is nagy sajtóvisszhangot keltettek, ami által egy alapvetően ritkán tárgyalt téma, a művi abortusz is az érdeklődés homlokterébe került.

Kutatásunkban azt vizsgáljuk, hogy milyen diskurzus bontakozik ki a müvi abortusszal, a szabályozás szigorításával, teljes tilalmával kapcsolatban a magyar online médiában. Elsősorban arra fókuszálunk, hogy milyen fogalmi keretben, képzettársítások, asszociációk hálójában jelenik meg a művi terhességmegszakítás, illetve az abortuszt választó nő a gyűjtött cikkekben. Kiemelt szempont, hogy a szövegek állításai mennyire állnak szinkronban a kurrens szakirodalom eredményeivel ${ }^{9}$, illetve a statisztikai adatokkal.

\footnotetext{
${ }^{9}$ Jelen kutatásban azt a - nemzetközi szakirodalomban elfogadott - álláspontot követjük, miszerint a művi abortusznak jellemzően nincs negatív hatása a nők mentális egészségére, az abortuszt követő negatív pszichés következmények gyakran inkább egyéb prediszpozíciók függvényeként jelennek meg (Steinberg - Rubin 2014). Mindemellett fontos leszögezni azt is, hogy számtalan módon élhetik meg a nők múvi abortuszukat, a traumatikustól kezdve akár a pozitív élményekig (American Psychological Association Task Force on Mental Health and Abortion 2008).
} 


\section{KÖZELKÉP - Tanulmányok}

A nők reprodukciós egészségének médiareprezentációját vizsgáló kutatások nagy része az Amerikai Egyesült Államokból származik (Purcell et al. 2014), hasonló magyar vizsgálatról nincs tudomásunk.

A kutatásunkat kvalitatív módszer alkalmazásával végeztük, mivel ez alkalmas leginkább egy adott téma kapcsán a diskurzusban a szóhasználat és megfogalmazás révén megjelenő mintázatok felismerésére és azonosítására (Miles - Huberman 1984). A kutatást a kritikai elméleti keretrendszerben (Calhoun - Karaganis, 2001) a konszenzuális kvalitatív kutatás (Hill, Thompson - Williams 1997) elemeit felhasználva, a tartalomelemzés módszerével végeztük. A kritikai elméleti keretrendszerben az értelmezéseket befolyásoló ideológiai, politikai, gazdasági és társadalmi tényezők is megérthetővé válnak. A konszenzuális kvalitatív kutatás elsődleges jellemzője több kutató együttmúködése az értelmezések, jelentések kritikai elemzésében.

A kutatói szándék az elemzés során nem az ok-okozati kapcsolat feltárása, hanem a leíráson alapuló megértés volt, vagyis: „a diskurzusban megjelenő alternatív tudatformáknak, az őket alkotó kijelentések rendszerének, az általuk hordozott kimondatlan előfeltevéseknek, valamint az ezeket megjelenítő szereplőknek az azonosítása." (Glózer 2007: 263)

A cikkeket tematikus elemzéssel (Braun - Clarke 2006) vizsgáltuk, és az adatokat szövegekben azonosított témakörök, mintázatok által strukturáltan elemeztük. Az adatgyűjtést és elemzést nem egymást követő munkafázisokként, hanem a munka során folyamatosan végzett eljárásokként kezeltük (Meyer 2001). A kódolás első lépése a múvi abortusz pszichés következményeit (illetve azok hiányát) tárgyaló szakirodalom alapján deduktív kategóriák kialakítása volt, amelyeket többszörös olvasási fázis során induktív kategóriákkal egészítettünk ki.

A kutatáshoz a vizsgálandó cikkeket a 2016. április és 2017. július közötti időszakból gyűjtöttük, mivel a lengyel abortusztörvény kapcsán ebben az időszakban jelent meg jelentős számú publikáció a magyar online médiában. A szövegek forrásai az adott időszakban legolvasottabb 50 internetes oldal közül azok voltak, amelyeken az alábbiakban bemutatott keresési eljárással legalább egy cikket találtunk. Ezen oldalak egy része általános közéleti portál, más részük online női magazin volt. Az olvasottságot a Digitális Közönségmérési Tanács olvasottsági adatbázisa (OLA) használatával, a „real user” 10 mutató alapján felállított sorrend szerint értelmeztük. A cikkek kereséséhez a honlapok saját kereső motorját, illetve a www.google.hu keresőmotort vettük igénybe. A keresőszavak az „abortusz”, „terhességmegszakítás”, „lengyel”, „tüntetés”, „törvénytervezet”, „tiltakozás” „Lengyelország” voltak. Az elemzésbe végül 17 internetes oldalról ${ }^{11}$ összesen 105 cikk (szószám: 59 940) került be.

\footnotetext{
${ }^{10}$ Real user: azok a felhasználók, akik a megadott időszakban a kiválasztott webhelyet meglátogatták (legalább egy oldalletöltést kezdeményeztek). Ez a mutató a felhasználó személyek számára utal, nem a számítógépekére, a cookie-k számára vagy az IP címek számára.

${ }^{11}$ index.hu, origo.hu, nlcafe.hu, blikk.hu, 24.hu, hvg.hu, 444.hu, borsonline.hu, szeretlekmagyarorszag.hu, life.hu, vs.hu, divany.hu, napi.hu, hirado.hu, mno.hu, rtl.hu, faktor.hu
} 


\section{KÖZELKÉP - Tanulmányok}

Az elemzéshez az ATLAS.ti 6.2-es kvalitatív adatelemző szoftvert használtuk. A kiválogatott cikkek feltöltésével kialakult szövegkorpuszban hoztunk létre kódokat, melyeket később a szakirodalom és kutatási kérdés szempontjából relevánsakra redukáltuk. A kódok egységei szavaktól a teljes bekezdésekig terjedtek. Többszöri olvasás és a szakirodalmi háttér újbóli áttekintése után a kódokból az egyes témákat lefedő kódcsaládokat alakítottunk, amelyek az elemzés alapját képezték.

\section{Eredmények}

A kutatás során azt vizsgáltuk, hogy az online sajtóban megjelent cikkek milyen fogalmi keretbe helyezik el a művi abortusz kérdéskörét, milyen tartalmakkal asszociálják azt, mivel ez fogja alakítani az olvasó képzettársításait, és így befolyásolja véleményalkotását is.

A továbbiakban a társadalmitól az egyéni szint felé haladva tárgyaljuk azokat a kereteket, illetve érvelési rendszereket, amelyekben a müvi terhességmegszakítás a vizsgált szövegekben megjelent, kitérve a társadalmi kontextusnak, a művi abortuszszal kapcsolatos attitűdöknek, az önrendelkezés jogának, és - egyéni szinten - a terhességmegszakítás bemutatott okainak és következményeinek kérdéseire.

\section{A MÛVI ABORTUSZ MINT TÁRSADALMI KÉRDÉS}

Az elemzett szövegek egy részében (elsősorban a cikkekben és kommentárokban) a terhességmegszakítás társadalmi kérdésként tematizálódik.

A művi abortuszok számának változása, illetve az abortuszok betiltása kapcsán jelenik meg az az érvelési mód, amely az abortuszok számának növekedését a népességfogyással, csökkenését a népesség növekedésével köti össze. A szövegek erre a demográfiai keretezésre gyakran hivatkoznak ugyan, de az inkább történelmi utalás formájában jelenik meg: a múltban (jellemzően a Ratkó-korszakban) már volt példa régiónkban szigorú abortuszszabályozás bevezetésére, melynek célja a népesség növekedése volt, az intézkedés azonban az illegális, nem biztonságos abortuszok számának radikális növekedését vonta maga után.

„A történelem során pedig már párszor egyértelművé vált, hogy a korlátozó népesedéspolitikai eszközökkel nem lehet tartósan befolyásolni a népszaporulatot. Még akkor sem, ha ennek köszönhetöen egyes években demográfiai csúcsok születtek, szó szerint.” (divany.hu)

Az abortusztilalom és a népességszám növekedése közti összefüggés az abortuszellenes (pro-life) retorika egyik eleme, ami ebben a kontextusban, az abortusz- 


\section{KÖZELKÉP - Tanulmányok}

törvény szigorítása mellett állást foglalók, illetve egy életvédő szervezet elnökének véleményeként is megjelenik:

„Irigylem a lengyeleket, mert lakosságuk az 1951. évi 25 millióról napjainkra 38 millió före gyarapodott, míg a mi lélekszámunk 1980 óta folyamatosan csökken, és ma már nem éri el a tízmilliót sem. Ennek egyik oka, hogy a lengyelországi terhességeknek mindössze 0,16 százaléka végződik abortusszal, míg ugyanez a tízmillió alá csökkent népességü Magyarországon 30,9 százalék!" (mno.hu)

„Az abortusztörvény szigorítása mellett érvelök hazánkban általában a Ratkókorszakot szokták felhozni példaként, amikor a terhességmegszakítás betiltása és a gyermektelenségi adó bevezetése után példátlan bébibum következett be Magyarországon, radikálisan javítva a népességi adatokat." (nlcafe.hu)

Utóbbi kapcsán azonban a szerző ezt a nézetet ellenpontozó állásfoglalása következik:

„Persze az ilyen jellegű statisztikában az olyan árnyékinformációk rendre nem szerepelnek, mint például az, hogy a szigorítás miatt hányan lettek öngyilkosok, hányan fordultak illegális eszközökhöz a magzat eltávolítása érdekében, ahogy az sem, hogy a társadalmi kényszer hatására megszületett, de senki által nem óhajtott gyerekekre később milyen sors várt Magyarországon." (nlcafe.hu)

Ahol abortusztilalom demográfiai keretezése direkten (a szerző/újság saját véleményeként, nem történelmi kontextusban) jelenik meg, ott a terhességmegszakítás tiltásának és a népességnövekedésnek az összefüggését jellemzően elutasítják:

„Demográfiai növekedést várhatóan nem eredményezne a javaslat, csak az illegális magzatelhajtások, a születési halálozások száma és az abortuszturizmus növekedne." (index.hu)

A történelmi kontextus másik jellemző eleme a terhességmegszakítás és a nácizmus faji politikájának összekötése. Ez az érvrendszer az abortusz teljes betiltásáért síkra szálló lengyel politikusok és aktivisták által használt, abban a vérfertőzés, erőszak során fogant, illetve a sérülten született csecsemők abortálása és az alsóbbrendűnek tekintett lengyelek körében engedélyezett (míg Németországban, a „tiszta faj” védelmében tiltott) abortusz között vonnak párhuzamot. A hírek és cikkek ezt a tematizálást rögzítik, de jellemzően nem reagálnak rá. 


\section{KÖZELKÉP - Tanulmányok}

A művi abortuszt alapvetően társadalmi problémaként kezelő keretezésben kivétel nélkül a terhességmegszakítások számának csökkenése/csökkentése jelenik meg kívánatos irányként vagy célként, ami ebben a összefüggésben társadalmi szintủ, proaktív beavatkozás formájában képzelhető el - ilyen lehet például a fogamzásszabályozás eszközeinek általánosan elérhetővé tétele és a szexuális nevelés gyakorlatának fejlesztése.

„Egy társadalomnak alapvető feladata (lenne) mindent megtenni, hogy a lehetséges minimumra csökkentse az abortuszok számát, de ehhez nem tilalomra, hanem többek között oktatásra, tájékoztatásra, tanácsadásra, elérhetô és megfizethető (vagy ingyenes) fogamzásgátlásra van szükség." (divany.hu)

Az abortusz társadalmi szintű tematizálásának következő lényeges eleme a vallás. A szövegek gyakorta említik, hogy Lengyelország Európa legvallásosabb országa, ahol a vallásukat gyakorlók aránya is kiugróan magas, és ez a tény jelenti azt a tágabb értelmezési keretet, amely hátterében a lengyelországi események megérthetők. Ez azért fontos, mert így deklarálódik a médiatartalmakban az, hogy a terhességmegszakítás szabályozásáról csak az adott társadalmi kontextus figyelembevételével lehet érvényes állásfoglalásra jutni. A közéleti portálok tényközlő műfajok közé sorolható írásaiban a hangsúly a kormányzati döntésen, és nem direkten a katolikus vallási meggyőződések szerepén van:

„Lengyelországban ez a kérdés történelmileg sokkal mélyebb és politikailag összetettebb, mintsem hogy azt bárki jó és rossz harcára egyszerüsíthetné, vagy hogy azt általánosítva az egész katolikus egyházra, és minden keresztény emberre kiterjeszthetné" (hvg.hu)

A véleményközlő írásokban ugyanakkor az állami/politikai szint alig jelenik meg, helyette a (katolikus) vallás dogmái állnak szemben az önrendelkezési joggal vagy egyszerűen a (női) szabadság eszméjével. Ebben a polarizációban a vallást a tudatlansággal, a „barbár sötétséggel” azonosítják, amely szemben áll a józan ésszel, az egyház pedig a hatalmával (vissza)élő, maradi, „keresztény terrorizmussal” fenyegető szervezetként jelenik meg:

„A lengyel példából világossá válik, hogy az aljasság, a gonosz korlátoltság megtámasztására minden vallás alkalmas. Hiszen ezeknek az intézményeknek az a funkciójuk, hogy középkori vagy ókori normákat örökítsenek át, minél kevesebb változtatással." (hvg.hu)

Az abortuszszabályozás kérdései részben a lengyel törvénytervezetben foglaltak rögzítésén, részben más európai (főként ír) példák említésén, részben pedig a ma- 


\section{KÖZELKÉP - Tanulmányok}

gyar szabályozás (általában minősítésektől mentes) leírásán keresztül tematizálódnak. Néhány szöveghelyen találtunk explicit utalást arra, hogy a törvényi szabályozásról nem a tilt/támogat dichotómiában érdemes gondolkodni, illetve hogy attól még, hogy valaki alapvetően ellenzi az abortuszt, nem feltétlenül ért egyet a teljes tilalommal, illetve aki ellenzi a tiltást, az nem feltétlenül támogatja az abortuszt vagy annak teljes liberalizációját:

„Amikor arról beszélünk, hogy itthon megengedő a szabályozás, azt nem szabad azzal összemosni, hogy a magyar rendszer »bátorítana az abortuszra: egyszerűen csak arról van szó, hogy nem zár el tôle." (divany.hu)

„bár a lengyelek döntô hányada elítéli az abortuszt, a szigorítással csak elenyészően kevesen értenek egyet" (blikk.hu)

Általában véve elmondható, hogy a vizsgált tartalmak között egy sem volt, ami a lengyel törvénytervezettel direkten szimpatizált volna. A hírekben (a műfaj természeténél fogva) nem találunk értékelő jelzőket, a publicisztikákban jellemzően embertelen, kegyetlen, túlzó intézkedésként írják azt le, és a fókuszba inkább a tiltás potenciálisan káros hatásai, negatív következményei kerülnek.

\section{Abortusz attitűdök: az abortuszháború}

Bár - mint a fentiekben említettük - a médiatartalmak reflektálnak arra, hogy a múvi abortuszról való gondolkodás nem feltétlenül az elfogad/elutasít dichotómiát kell, hogy kövesse, illetve az, ahogy az abortuszról vélekedünk, az egyén meggyőződéseinek, gondolkodásmódjának, tapasztalatainak függvénye, a szövegeket leggyakrabban mégis az életvédők és nők, nőjogi aktivisták szembenállása tematizálja. A polarizáltság megjelenítésében a teljes tilalommal kapcsolatos egyházi és kormányzati álláspontok, illetve a tüntetők véleménye a legtöbbször előforduló elemek, amelyeket a szövegek műfaji sajátosságaiktól függően minősítenek vagy hagynak reflektálatlanul.

Az ellentétek bemutatásának gyakorta és visszatérően alkalmazott nyelvi eszköze a militáns, háborús szóhasználat:

„az abortusz harcos ellenfele” (hvg.hu)

„a kormányzó párt új frontot nyithat a társadalom átformálásában” (hvg.hu)

„az abortusz elleni harcban a puhább, erôtlenebb taktikák már nem múköd$n e k^{\prime \prime}(\mathrm{rtl} . \mathrm{hu})$ 


\section{KÖZELKÉP - Tanulmányok}

A szembenállás olyan módon is reprezentálódik, hogy mindkét fél elszántan és eltántoríthatatlanul „mindent megtesz” a saját elvei vagy érdekei képviselésére: a terhességet kihordani nem szándékozó nők annak megszüntetéséért (beleértve az illegális abortuszt is), a lengyel kormány és az életvédők pedig „az emberi élet védelmének érdekében" képesek bármire. A konnotáció egyértelműen negatív: olyan aktusokról van itt szó, amelyeknél a cél szentesíti az eszközt.

Egy helyütt reflektál a véleménycikk szerzője erre a megosztottságra, maga is a militáns szóhasználatot folytatva:

„Ki kellene végre szállni »a magzat élethez való joga« kontra »a nő választási joga « kifejezésekkel felcímkézett lövészárkokból, amelyekben a nő és születendő gyereke egymás ellenségének van beállítva." (mno.hu)

A terhességmegszakítás kérdését „militarizáló” kifejezésmód alapvetően alkalmas arra, hogy érzelmileg-indulatilag színezetten beszéljen a témáról, másrészt azt is implikálja, hogy a kérdés kapcsán valahová állni kell, egyértelműen állást kell foglalni egyik vagy másik oldal mellett, illetve valamelyik nézőponttal szemben.

A polarizáltság vagy direkt oppozíció azonban nem csak az életvédők és választáspártiak ellentéteként tematizálódik, legalább ilyen hangsúlyos a téma kapcsán a nők és férfiak szembenállásának kérdése. Ez részben közvetlenül a lengyelországi eseményekből fakad, ahol a törvényi szigorítás elleni tiltakozás egyik legfontosabb üzenete az volt, hogy ne férfi politikusok mondják meg, mit tehetnek a nők a testükkel - amint az számos írásban (tájékoztató és véleményközlő műfajú írásokban egyaránt) megjelenik. Mivel a férfiak nem képesek szülni, ezért döntést hozni sem lehet(ne) joguk, ahogy azt a tüntetők másik, többször idézett jelmondata is megfogalmazza („Az abortuszellenes vezetők 77 százaléka férfi. Az ő 100 százalékuk sohasem lesz terhes.")

A másik oldal, a női összefogás kapcsán gyakorta említik a szövegek azt a mondatot, amelyet az aktivisták/tüntetők Beata Szydlo kormányfőnek címeztek: „A pokolban külön hely van azoknak a nôknek fenntartva, akik nem támogatják nootársaikat." Ezen kívül a női szolidaritás az elemzett szövegekben egyáltalán nem jelenik meg.

A véleménycikkek közül néhány, jellemzően női portálon fellelt, az abortusztilalomról szóló írás hangneme kifejezetten indulatos, nyelvezete érzelmileg túlfütött, akár szitkozódó. Ezekben az írásokban visszatérő téma a döntéshozó lengyel férfi politikusok ostorozása:

„Na ehhez tényleg csak lassan tapsolva lehet gratulálni, mielött csendben elsírnánk magunkat a tehetetlen düh érzésétöl. Ti szerencsétlen, többségben férfi okostojások, igen, hozzátok beszélek, kedves döntéshozók, akik megálmodtátok ezt az érfalrepesztő baromságot! Nagyon tetszik, amit a narancssárga őrült csinál az Atlanti-óceán túloldalán, ugye? Ahogy döntött a nök tes- 


\section{KÖZELKÉP - Tanulmányok}

térôl, az is klassz, ugye? Hát, mekkora férfi, hogy megmondta, hogy ki mit csinálhat és mit nem csinálhat a saját testével." (nlcafe.hu)

Jellemző, hogy a fókuszban nem az áll, hogy ki jogosult dönteni a terhesség megtartásáról vagy megszakításáról (az anya vagy bárki más), hanem hogy a döntés női vagy férfi jogosultság-e. A kommentárok, publicisztikák szerzői gyakran hivatkoznak arra, hogy a lengyel parlament szinte csak férfiakból áll, többségében „meglett korú férfi politikusok" alkotják, akiknek nem szabadna beleszólni az abortusz kérdésébe. Azt az írások nem tematizálják, hogy vajon egy női többségű parlament más jogosultságokkal bírna-e, illetve implicite azt sugallják, hogy egy ilyen törvénytervezet csak egy férfiak által uralt világban születhet meg.

A szövegek másik csoportjában, ahol az abortusz kérdése szintén ab ovo női témaként jelenik meg, a hangsúly inkább mások (leginkább a férfiak) érintettségének elvitatására vagy szempontjaik kizárására kerül:

„Senkinek semmi köze hozzá, mert ez a nő saját döntése.” (nlcafe.hu)

„Ez a döntés ugyanis kizárólag egyetlen emberé: azé, akinek a testérôl és az életérôl szó van." (nlcafe.hu)

„Egyáltalán hogyan lehetséges, hogy ilyen kérdésekbe bármelyik férfinek egyáltalán beleszólása van?" (nlcafe.hu)

A férfiak érintettsége egyetlen szövegben, egy életvédő szolgálatban dolgozó nő írásában jelenik meg:

„És akkor még nem beszéltünk a többi családtagra gyakorolt hatásról [...] a férfi tehetetlenségéröl, akinek nincs joga megvédeni a saját gyereke életét."

Bár ez a szöveg is így folytatódik:

„Az abortusznak két áldozata van: a nő és a gyereke.” (mno.hu)

\section{Az abortusz mint a (testi) önrendelkezés joga}

A női portálokon és a híroldalakon egyaránt megjelenik az a keretezés, amelyben az abortusz tiltása a nők saját testükkel kapcsolatos önrendelkezési jogának megsértéseként értelmeződik. Ez az érvrendszer a választáspárti attitűd egyik legfőbb eleme, ezért a törvénytervezet elleni tüntetések gyakorta idézett jelmondatai is erre reflek- 


\section{KÖZELKÉP - Tanulmányok}

tálnak („az én testem az én választásom”, illetve „a testem nem inkubátor”), és a cikkekben megszólaltatott választáspárti aktivisták is ezt használják („aki bele akar szólni a nők testi önrendelkezésébe, az erôszakoskodik és a nők életével játszik."). Az elemzett szövegekben az önrendelkezés kérdése nemcsak bemutatott reprezentációként, hanem a szerzők saját véleményeként is gyakorta megjelenik:

„Akit pedig a teste és sorsa fölötti rendelkezésben korlátoznak, azt abban korlátozzák, hogy saját személye fölött döntsön. Ha egy állam megtiltja a legális abortuszt, azzal a nőket alapvető emberi jogaiknak gyakorlásától fosztja meg." (divany.hu)

„Lengyelország szeretne visszamenni az időben, hogy látványosan sárba tiporja a nők saját testükkel kapcsolatos önrendelkezési jogát.” (nlcafe.hu)

A véleményközlő cikkek előszeretettel használják ezt a keretezést, amelyben az önrendelkezés jogának elvitatása egyre tágabb kontextusba helyeződik: a saját test feletti döntés korlátozása egyenlővé válik a nők jogainak semmibe vételével, vagy akár a nőkön tett erőszakkal.

„Ha kétségbe vonják a nők jogát az abortuszhoz, attól csak pár lépés a kötelező fogamzásgátló-használat vagy a sterilizáció." (hvg.hu)

„az abortusztiltás célja, hogy a fennálló hatalom igényei szerint szelektált (azaz fehér, középosztálybeli) női testekből akár kényszerrel és halálos áldozatok árán is kisajtolja reproduktív kapacitásuk maximumát" (mno.hu)

„Megfosztaná a nőket a testük, végső soron pedig a saját sorsuk fölötti rendelkezéstől, egyszerü »szülőgéppé« degradálva őket." (blikk.hu)

Ezekben a cikkekben úgy érvelnek, hogy a terhesség a nő testében zajló folyamat, így az abortusszal kapcsolatban a döntés, a választás joga őt illeti, de emellett a test feletti kontroll a hatalomgyakorlás kérdéseként is tematizálódik. Ez direkten a választáspárti oldal bemutatott reprezentációjaként jelenik meg (amelyre a cikk maga, illetve a szerző nem reagál):

„A magzat nevében azok ellen a nők ellen fellépni, akiknek a teste nélkül a magzat életképtelen lenne, álságos, azaz nem a magzatot védi, hanem a nők teste feletti és azon keresztül az erőforrások feletti kontrollt valósítja meg." (index.hu) 


\section{KÖZELKÉP - Tanulmányok}

A test és hatalom kérdése azonban a választáspárti attitűd deklarálása nélkül, mintegy alapvető tézisként is megjelenik, jellemzően a cikkek (al)címeiben, annak részletes kibontása nélkül:

„Amikor a nők teste felett a politikusok rendelkeznek.” (life.hu)

„Birtokba vett testek.” (mno.hu)

Az önrendelkezés jogának megsértése és a test feletti kontroll elvitatása egyben a nők döntésre képes felnőtt szerepének megkérdőjelezését is jelentheti:

„A nők döntési joga a tét, az, hogy felnőtt emberként maguk határozhassanak a testükről." (nol.hu)

„Az élethelyzet valós felmérésének képességét nem kellene elvitatni senkitől” (mno.hu)

\section{Az abortusz-döntés és okai}

Láthattuk, hogy a terhességmegszakítás lehetősége mint az önrendelkezéshez való jog visszatérő eleme a témával foglakozó írásoknak. Ennek kapcsán felmerül az a kérdés is, hogy az elemzett médiatartalmak hogyan kezelik az abortusz-döntést: döntenek, dönthetnek-e a nők autonóm módon terhességük megszakításáról.

A vizsgált cikkekben azokban az esetekben, amikor a nők döntését hangsúlyozó megfogalmazást találunk, ezzel együtt gyakorta az is megjelenítődik, hogy a döntés valamilyen szükségszerűség, kényszer következménye, vagyis ilyen értelemben csak látszólagos az autonómia:

„Tisztában vagyok azzal, milyen nyomás késztette őket erre a döntésre." (nlcafe.hu)

„Egyetlen nő sem jószántából dönt az abortusz mellett.” (life.hu)

„Szabad választásról úgyis bajosan beszélhetünk - a minket megkeresők többsége vagy súlyos nyomás vagy információhiány következtében döntött az abortusz mellett." (mno.hu)

A véleménycikkek más részében inkább a nők passzív szerepe kap hangsúlyt, akár a helyzet kialakulása, akár annak megoldása kapcsán: 


\section{KÖZELKÉP - Tanulmányok}

„Azok a nők mennek börtönbe, akiknek becsúszott egy terhesség.” (nlcafe.hu)

„Bajba került lányok és asszonyok.” (napi.hu)

„Az illegális magzatelhajtásokkal együtt nagyjából 150 ezer terhességmegszakítást hajtanak végre lengyel nókön." (mno.hu)

„Kinek könnyú kórházi hálóingben magasra feltett, leszíjazott lábbal várnia, hogy kiürítsék"? (mno.hu)

A nők valódi, aktív szerepvállalása inkább az illegális és/vagy nem biztonságos abortuszok választásának kapcsán jelenik meg:

„A magzatuktól megszabadulni akaró nők kénytelenek voltak tömegesen illegális módszerekhez és sokszor nagyon is veszélyes házi praktikákhoz fordulni." (nlcafe.hu)

„A gazdagabb réteg más országokban intézi el, ha szüksége van rá, a szegényebb réteg pedig élete kockáztatásával házi módszerekkel igyekszik véget vetni a terhességnek." (nlcafe.hu)

A terhesség megszakítására irányuló döntés kapcsán érdemes megvizsgálni azt, hogy melyek azok az okok, amelyek miatt a nők az abortuszt választják. Amikor a várandósságról való lemondás lehetséges indokairól általában véve van szó a cikkekben, megjelenik a téma több szempontú, az egyéni élethelyzetet mint a döntés kontextusát is figyelembe vevő megvitatása. A cikkek és kommentárok rámutatnak arra, hogy a nők különböző okokból és körülmények között választhatják az abortuszt - az egyéni élethelyzet mérlegelése szintén a már említett választáspárti attitűd lényegi eleme, még ha a szövegekben ezt direkten nem is említik meg.

„A nók számára viszont, akik akaratuk ellenére teherbe esnek, ez nem elvi, hanem gyakorlati, és nem általános, hanem egyéni kérdés. Olyan kérdés, amire nem elvont eszmék, hanem a saját élethelyzetük alapján kénytelenek választ adni." (divany.hu)

„A nők azért választják ezt a megoldást, mert átgondolták, és arra jutottak, hogy a jövőbeli gyereket nem képesek felelősségteljesen felnevelni. Vagy már van gyerekük, vagy egyedül vannak, vagy a férjük beteg, de nem megy egyszerüen, MOST nem tudják vállalni." (life.hu) 


\section{KÖZELKÉP - Tanulmányok}

A döntés okaként a fentiek mellett a tudatlanság/információhiány, illetve a magzat elvetetése irányába ható külső nyomás nevesítődik.

Megvizsgáltuk az abortusz okait akkor is, amikor a terhesség megszakítására irányuló döntésről nem általánosságban, hanem az egyedi történetek vonatkozásában esik szó. A cikkek közül kilencben összesen 18 személyes történet ${ }^{12}$ jelenik meg, ebből ötben szerepel legális abortusz, amelyet az érintettek a következő okok miatt választottak: fiatal életkor, nemi erőszak során fogant magzat és az iskolai tanulmányok folytatása.

\section{Az abortuszt választó nők}

Az abortusz kapcsán - evidens módon - az anyaság az a női szerep, ami leggyakrabban előtérbe kerül.

Gyakori, hogy a terhességük megszakítását kérvényező nőkre a szövegekben anyaként hivatkoznak. Ez egyrészt abból adódik, hogy az orvosi indikációjú abortuszra konzekvensen és kizárólagosan az „,anya életveszélye esetén” fordulattal utalnak, de más szöveghelyeken is (pl. egy vállaltan választáspárti megszólaló véleményét közölve, illetve a terhességmegszakítás történetét bemutató írásban) az abortáló nő anyaként nevesítődik:

„Ezért ők is azt vallják: bár minden lehetséges eszközzel el kell kerülni a terhességmegszakítást, ha azonban erre még sincs mód, akkor az anya számára legbiztonságosabb, testileg-lelkileg legkevésbé megterhelő utat támogatják." (divany.hu)

„Ahogy a technológia és a tudomány fejlődött, az abortusz egyre kisebb veszélyt jelentett az anya életére." (index.hu)

Ezzel kapcsolatban megjelenik a művi abortusznak az az - életvédők retorikájának fontos elemét jelentő - tematizálása is, amelyben a terhesség megszakítása az anyaság elutasításaként vagy el nem fogadásaként tételeződik, igaz, dirket formában csak egy helyen, egy életvédő aktivistától átvett (és a cikkben reakció nélkül hagyott) reprezentációban:

„Oda kellene állni a többnyire komolyan vívódó nő mellé, és ítélkezés vagy moralizálás helyett abban segíteni, hogy elfogadja az anyaságát.” (mno.hu)

\footnotetext{
${ }^{12}$ Személyes történeten azt értjük, amikor egy cikkben egy konkrét élettörténet vagy annak részlete szerepel, akár az érintett személy, akár valaki más számol be arról (Woodruff, 2019).
} 


\section{KÖZELKÉP - Tanulmányok}

Ugyanitt az abortusz „anya és gyermeke kapcsolatának erőszakos megszakítása"-ként említődik.

Máshol a gyermekvállalás mint ideális helyzet, a várandósság mint „csodás időszak" (life.hu) tematizálódik, amit a nők szeretnének, de nehéz körülményeik miatt nem tudnak vállalni. A fogantatás tényére adott univerzális reakció az öröm, ami helyett egyes - az abortusz indokaként szolgáló - élethelyzetekben inkább a kétségbeesés jellemző.

Az anyaság a fentieken túl - jellemzően a véleménycikkekben - a kényszerterhességek (nem kívánt, de a szabályozás miatt nem elvetethető magzatok kihordása) kapcsán jelenik még meg, ezekben az esetekben az anyai szerep nem idealizált, a „kényszerü anyává válás” (mno.hu) inkább nehéz teherként tételeződik:

Tényleg azt hiszik, hogy az anyja majd felhötlen szeretettel tud felé fordulni, mikor minden percben arra emlékezteti a saját gyereke, hogy megerőszakolták? Boldogan öleli majd magához? Mementóként kísérje végig az egész életét? Kinek jó ez? (nlcafe.hu)

Az abortuszt választó nők csoportját több helyütt is olyan, a társadalmon belüli szubpopulációként ábrázolják, akik valamilyen szempontból hátrányos helyzetűek:

„Ha szerdán megszavazzák a javaslatot, azzal megerőszakolt nöket, gyerekeket fognak a terhességük kihordására kényszeríteni, rengeteg, egyébként is hátrányos helyzetű nőt fognak életveszélyes és akár ötéves börtönbüntetéssel fenyegető abortuszkísérletekbe hajszolni." (444.hu)

„Természetesen éppen az alacsonyan iskolázott és szegénységben élő rétegeknél maradt a múvi abortusz a fogamzásgátlás eszköze, de nem pusztán a megfelelő ismeretek hiánya áll a jelenség mögött. Hiszen ha nincs pénz kenyérre, tejre, parizerre, a havonta kiváltandó, több ezer forintba kerülő fogamzásgátló tablettára aligha lesz. A felvilágosult középosztály nyilvánvalóan ismeri, használja és megengedheti magának a fogamzásgátlás különféle és ma már szinte százszázalékos hatékonyságú eszközeit..." (mno.hu)

Az abortuszról szóló személyes beszámolókban az érintett nők jellemzően fiatalok. A 19 egyéni történetből tíznél derül ki az érintett nő életkora, ebből hat 18 év alatti, három 21 és 25 év közötti, és egy 31 éves. Ha csak azokat a történeteket nézzük, ahol biztonságos abortusz végrehajtásáról van szó (tehát nem illegális terhességmegszakítás vagy épp az abortuszkérelem elutasítása a téma) az érintett nő életkora mind az öt esetben ismert: 13, 14, 16, 18 és 21 év. 


\section{KÖZELKÉP - Tanulmányok}

\section{Az abortusz következményei}

Bár az abortusszal járó veszélyek kapcsán a legtöbb esetben az illegális terhességmegszakítások vannak a fókuszban, több cikkben és kommentárban is eltúlozzák a művi abortusz fizikai egészséget érintő kockázatainak valószínűségét. A (biztonságos) müvi abortusz súlyos következményeiként dominánsan inkább a pszichés velejárók szerepelnek a szövegekben, mint például a „nem csillapodó, életet elszívó fájdalom" (mno.hu).

A terhességüket megszakíttató nők élményeinek említésekor a körülményeiket jellemzően súlyos válsághelyzetként ábrázolják, a nők abortusz előtti vívódását, abortusz utáni lelki fájdalmait, annak nehéz feldolgozhatóságát hangsúlyozzák. Az abortusz gyakran tematizálódik „drámaként”, „tragédiaként”, illetve „traumaként”, ami „igen kockázatos”, és „a nöt megkínozza mind testileg, mind lelkileg.” (24.hu)

E témakör kapcsán a legkirívóbb véleménycikknek már a címe is kifejezetten általánosító és túlzó: „Abortusz, amikor a lelked egy részét is elveszted”. Az írás - bár a terhesség megszakításához vezető okokat egyéniként, személyesként említi - alapvetően homogénnek állítja be a nők abortuszélményét (olyan kifejezéseket használva, mint pl. „a nők többsége úgy tesz”), általánosítva ezzel a lelki megpróbáltatást, pszichés distresszt, traumát, mely utóbbi feldolgozásáig az írás szerint a legtöbb nő el sem jut. A kommentárt ezzel a bevezető kérdéssel indítják:

„Le lehet-e tenni ezt a keresztet, vagy egész életében, láthatatlanul a vállán cipeli majd?"

majd ezzel a - tipográfiailag is kiemelt - sorral zárják:

„Az abortusz nem csupán egy lehetőség, nem a könnyebb út, nem egy alternatív megoldás. Az abortusz egy döntés, mellyel együtt kell élni. Az abortusz egy trauma, melyet fel kell dolgozni." (life.hu)

Azt találtuk, hogy a véleményközlő írásokban a művi abortusz nem annak semleges vagy pozitív keretezésével, hanem egy másik negatív kimenetellel, például a kényszerterhesség, szülésre kényszerítés következményeivel összevetve válik legitimizálhatóvá. Ezekben a szövegekben kiemelik, hogy a terhesség a nő sorsát és identitását radikálisan, akár negatív irányba alakítani képes helyzet, valamint hogy a kényszerből megszületett gyermekek helyzete ab ovo hátrányos.

„Ezek szerint azok a gyerekek között, akiket édesanyjuk a terhesség alatt szorongással, kényszerérzettel hordott ki, magas számban fordulnak elő mentális betegségek, és magasabb az öngyilkossági hajlamok aránya is.” (divany.hu) 


\section{KÖZELKÉP - Tanulmányok}

A terhesség megszakításával kapcsolatos semlegesebb, vagy akár pozitív élmények és attitűdök szinte teljesen hiányoznak a szövegekből. Egy kivétel az mno.hu-n olvasható, amiben Radnóti Miklós felesége, Gyarmati Fanni naplóbeszámolóját idézik. Itt az abortusz választása nem hosszas lelki vívódásként, hanem egy gyors, hideg fejjel hozott döntésként jelenik meg. Az, hogy a beavatkozás nem jelentett különösebben nagy kellemetlenséget a számára - „egy fogkezelés rosszabb ennél” - kifejezetten ellentétes az eddig megjelenő abortuszábrázolással. Az idézet után azt is megemlítik, hogy Gyarmati Fanninak öt abortusza volt a két háború között, mely időben jövőjük, egzisztenciájuk teljesen kilátástalan volt.

\section{Az abortuszhoz társuló asszociációk}

A művi abortusz a vizsgált szövegekben több aspektusból, visszatérően asszociálódik a halálhoz. Ez egyrészt az abortusznak a magzat megöléseként, gyilkosságként való említését jelenti, ez azonban csak elvétve, jellemzően a lengyel egyház álláspontjaként vagy életvédő szervezetek nyilatkozatainak idézésekor jelenik meg.

„egyes lengyel püspökök máris »halál civilizációjaként« bélyegzik meg a női jogok mellett kiállókat” (nol.hu)

„Az abortusztabletta egy ártatlan emberi élet kioltására alkalmas szer. Ilyen módon a halált jelképezi." (index.hu)

Ennél jóval gyakoribb a teljes abortusztilalom következményeként említett mortalitás, amely részben a nem kívánt terhességét elvetetni nem tudó nő öngyilkossága vagy csecsemőgyilkossága, részben pedig az illegális terhességmegszakítás halálos áldozatai kapcsán kap említést:

„A legrosszabb eset pedig az illegális abortusz, amibe évente 47 ezer nö hal bele a WHO adatai alapján" (nlcafe.hu)

„Olyan törvényt akarnak bevezetni, ami sok esetben felérne egy halálos ítélettel az anyára." (origo.hu)

„A törvényes abortusz hiánya gyilkol.” (az abortusz szigorítása ellen tüntető nők transzparenseinek gyakorta idézett szövege)

Szinte minden, a törvénytervezetről beszámoló cikkben megemlítik azt, hogy a bevezetni kívánt szabályozás sem a magzat életképtelensége, sem az anya életveszélye miatt nem engedélyezné a terhesség megszakítását, implikálva ezzel a gyermek 


\section{KÖZELKÉP - Tanulmányok}

és/vagy az anya halálát a szülés/születés alatt vagy után. Több helyütt is szerepel továbbá, hogy az abortusz az élet vagy a halál választása („Amikor életről és halálról döntenek a nök." - mno.hu).

Végül a halál szimbolikus formában is megjelenítődik akkor, amikor a szövegek a gyászruhás tüntetésekről számolnak be, amely viselet kultúránkban a halállal kapcsolatos szimbólumrendszerhez tartozik. Igaz, a fekete ruhába öltözve tiltakozó lengyel nők jogaik és jövőjük gyászolására utalva használják e szimbolikát, ez a magyarázat a cikkeknek csak kis százalékában szerepel.

„Feketébe öltöztek Lengyelországban a tüntető nők, reflektálva az illegális abortuszok számos halálos áldozatára.” (divany.hu)

A halál mellett a terhesség megszakítása az illegitim, illegális cselekvésekkel, és így a törvényen kívüliség képével is asszociálódik. Egyik ilyen, devianciaként kezelt helyzet az illegális terhességmegszakítás, amely gyakran erős részletezettséggel, vizuálisan elképzelhető módon, a vér, a fájdalom és a szenvedés leírásával együtt jelenik meg.

„»Azt mondta az orvos, hogy nem ad érzéstelenítôt, ha pedig sikítok, azt meghallják. [...] Nem kiálthattam - folytatja Connie -, de arra emlékszem, hogy annyira fájt, hogy testen kívüli élményem volt." [...] Azt is elmesélte, hogy miközben vérezve feküdt az illegális abortusz után egy ágyon, az ember, aki végezte rajta a beavatkozást, szexuálisan zaklatta." (nlcafe.hu)

A devianciák közül az abortuszhoz kötődően megjelent a cikkekben a bírósági vagy büntetőeljárás és a börtönbüntetés lehetősége (a magzatát elvetetni akaró nő és/vagy az abban segédkezők, elsősorban az orvos bebörtönzése kapcsán), amely a törvényesség hiányát kapcsolja a művi vetéléshez, valamint a prostitúció is, amenynyiben a szövegek kiemelik, hogy a megmozdulásokon egyben a szexmunkások jogaiért is tüntettek. Magát a törvénytervezetet, annak működési elvét több helyütt hasonlítják a szigorú drogpolitikához vagy a tűcsere-programok betiltásához. Ugyan nem illegális, de egyértelműen negatív jelenségként, a tilalom káros következményeként, illetve a törvényi szabályozás megkerüléseként jelenítik meg a cikkek az abortuszturizmust, vagyis azt a jelenséget, amikor a szigorú szabályozású országokból célzottan terhességmegszakításért másik országba utaznak el a nők.

„A tervezet szerint nem büntetnék az orvost a magzat haláláért, ha ezzel az anya életét menti meg, de a beavatkozást mindenképpen a bíróság fogja vizsgálni, és a bíróság fogja megállapítani, hogy bünös volt-e az orvos, illetve, hogy az anya szándékosan okozta-e a magzat halálát." (24.hu) 


\section{KÖZELKÉP - Tanulmányok}

„Becsukhatnák azt a nôt is, aki egy terhességmegszakító tablettát átad a barátnőjének - a túl szigorú drogtörvények szoktak így múködni." (nlcafe.hu)

„A tiltás viszont többet árt, mint használ. Így van ez a kábítószerekkel vagy a dohányzással, és nem kivétel ez alól az abortusz sem.” (divany.hu)

A szexualitás az abortusz kapcsán szinte kizárólag deviáns, kriminalizált formában (nemi erőszak, vérfertőzés) jelenik meg.

„Még a nemi erőszakból vagy vérfertőzésből fogant magzatokkal sem mehetnek abortuszra az anyák. Elképesztő." (nlcafe.hu)

„Azért kellett vállalnia a megpróbáltatást, mert az ostromlott fövárosban védtelenül maradva szovjet katona eröszakának esett áldozatul.” (mno.hu)

\section{Következtetések}

Kutatásunkban a tervezett lengyel abortusztörvény kapcsán a magyar online médiában megjelent szövegeket vizsgáltuk. Elsődleges célunk az volt, hogy a médiatartalmak elemzése révén információt nyerjünk arról, hogy a művi abortuszra vonatkozóan milyen reprezentációk azonosíthatóak a sajtószövegekben, a téma milyen keretezésben és milyen tartalmakkal asszociálódva jelenik meg a vizsgált tömegkommunikációs felületen.

A vizsgált médiatartalmak kapcsán általánosságban az mondható el, hogy azokban a művi abortusz kapcsán a választáspárti (pro-choice) attitűd nagyobb, az abortuszellenes vagy életpárti (pro-life) attitűd kisebb arányban tematizálódik. További fontos különbség, hogy míg az életpárti retorika kizárólag valakinek (pl. a lengyel kormánynak, életvédő aktivistáknak) a bemutatott reprezentációiként jelenik meg, melyet a hírportál vagy reflektálatlanul hagy, vagy megkérdőjelezi, ellenpontozza azt, addig a választáspárti érvrendszer és gondolatkészlet részben bemutatott ( $\mathrm{pl}$. tüntetők, hazai választáspárti szervezetek vélekedését közlő), részben saját (az újságíró vagy a lap állásfoglalását tükröző) reprezentációként kap helyet a szövegekben. Ez egyben azt is jelenti, hogy az abortuszellenes érvrendszer mindig jelölten (pl. „az abortusz tiltása mellett érvelők” véleményeként), a választáspárti többségében jelöletlenül, vagyis nem egy lehetséges nézőpontként, hanem általános (mindenki által osztott) igazságként jelenik meg.

Az elemzett szövegekben több helyen megfogalmazódik az az álláspont, hogy az abortuszhoz folyamodó nőket nem lehet egy homogén csoportként kezelni: mivel minden döntés egy adott élethelyzetben jön létre, ezért annak okai és következményei is különbözőek lehetnek. Azok a nyelvi megfogalmazások azonban, amelyekben 


\section{KÖZELKÉP - Tanulmányok}

az abortusz témája egy harcokkal teli, küzdelmes területként jelenik meg, mégis a véleményalkotás polarizáltságát (elutasít/támogat) erősítik. A harcias, érzelemtől túlfütött kifejezések használata, a felek szembenállásának nyomatékosítása az abortusszal kapcsolatos diskurzust végletesen konfliktusos területként keretezi. Ez a retorika azt sugallja, hogy az ellentétek kibékíthetetlenek, az álláspontok nem közelíthetőek egymáshoz, vagyis a terhességmegszakítás kérdése mindenkitől egy egyértelmű állásfoglalást igényel. Az, hogy a művi abortusz ismételten az általa keltett konfliktusok fényében jelenik meg, a társadalmi diskurzus szintjén ennek a megosztottságnak fennmaradásához járulhat hozzá (Purcell et al. 2014), az egyén vonatkozásában pedig magát a döntést egy polarizált térbe helyezi. Ráadásul ez a beszédmód, például a „gyermek életéért harcolunk” kifejezés az anya említése nélkül, mesterségesen szembeállítja a terhes nők és a magzat életét és érdekeit.

A korábbi kutatásokkal összhangban (Sisson - Kimport 2014, Sisson - Rowland 2017) megjelenik a szövegekben a terhességmegszakításnak a halállal való asszociálása, illetve a nem kívánt következmények (főként pszichés ártalmak) túlhangsúlyozása is. Ez azért problémás, mert a halállal kapcsolatos szimbólumok és a halállal végződő események (akár az anya halála, akár a magzat meggyilkolása) említése még akkor is, ha azok az abortusztilalom és/vagy az illegális abortuszok következményeként jelennek meg - tendenciózusan asszociálják a művi abortuszhoz a halál képzetét. Ez a fogalmi társítás aztán torzíthatja az abortusz legitimációjával és biztonságosságával kapcsolatos elképzeléseket, vagyis hozzájárul annak a feltételezésnek a fennmaradásához, hogy az abortusz fizikailag veszélyes eljárás (Sisson - Kimport 2014). Baird (2001) szerint a nem biztonságos abortuszok képszerü megjelenítése, a „szörnyűségeinek”, kockázatainak hangsúlyozása ahhoz vezethet, hogy az emberek a legális, orvosi körülmények között végzett abortuszt is patologikusnak, veszélyesnek tartják. A törvénytervezet szigorú drogpolitikához, tűcsere-program betiltásához való hasonlítása egy illegális tevékenység és az abortusz között von párhuzamot, és így az abortuszt választó nők csoportját egy deviáns, illegális tevékenysége miatt már eleve stigmatizált csoporttal hozza kapcsolatba. A terhességmegszakítás összekapcsolása a halál, gyilkosság, illegalitás képzeteivel a művi abortuszt egy sötét, zárt ajtók mögötti, veszélyes tevékenységként jeleníti meg, amely nem hagy diszkurzív teret annak, hogy az átlagos kockázatokkal járó orvosi beavatkozásként reprezentálódjon.

Az elemzett médiatartalmak kitérnek a terhességmegszakítás olyan, a társadalmi diskurzusban jelen lévő értelmezésére, mint a művi abortuszok számának demográfiai kontextusban megjelenő tárgyalása, vagyis az abortuszszabályozásnak a népességszám-emelés eszközeként való bemutatása. E tekintetben következetesnek mondható az a - tudományos szempontból is helytálló - üzenet, amely szerint a terhességmegszakítás szigorú szabályozása nem vezet az abortuszok alacsonyabb számához (Sedgh et al. 2012, WHO 2012, Marecek et al. 2017). A cikkek azt a kérdést 


\section{KÖZELKÉP - Tanulmányok}

nem tematizálják, hogy a népességszaporulat önmagában legitimálhatná-e a művi abortuszok elvégzésének tilalmát.

Az abortusszal kapcsolatos diskurzusnak az elemzés alapján domináns része az emberi jogi és az alapvető testi önrendelkezés jogával összefüggő keretezés. Ez a reprezentációs mód a női egyenjogúság szempontjainak érvényesülését támogatja, és - szemben a terhesség mesterséges megszakításának kizárólag medikális szemszögből történő tárgyalásával - egy adott társadalmi kontextusban érvényes tudást alakít ki, amely közös tudásnak része az, hogy minden nőnek joga van döntést hozni a saját teste fölött. Ez a diskurzus részben reflektál a fennálló társadalmi normákra, de egyben formálja is azokat, például az emberek elképzelését arról, hogy kinek és milyen feltételek között lehet indokolt a terhességmegszakítás (Dudová 2010).

A magyar online média diskurzusában egymás mellett van jelen a női testi önrendelkezés maximája és az abortusz általánosan negatív keretezése. Habár a múvi abortusz a testi önrendelkezés alapvető jogának kifejeződéseként hangsúlyosan megjelenik a szövegekben, a megfogalmazások mégis vitatják, hogy a nők valóban autonóm módon, szabad akaratukból választják a terhesség megszakítását. Ennek része az abortáló nők hátrányos helyzetének, áldozatiságának és a környezeti nyomásból fakadó kényszerítettségének hangsúlyozása, amely - amellett, hogy nem hagy teret az abortusz semlegesebb vagy akár pozitív keretezésének - megkérdőjelezi, hogy tényleg autonóm, felelősségteljes döntés tud-e lenni egy ilyen, kényszer alatt hozott választás. A terhességmegszakítás okozta nehézségek általánosként feltüntetése, a művi abortusznak életen át tartó teherként, krízisként vagy kifejezetten traumaként való keretezése, az örökké tartó vezeklés kényszerűségének nyomatékosítása az együttérzés kiváltása mellett a nőket saját döntésük áldozataként és következményeinek elszenvedőjeként mutatja be. Közben az abortuszt követő mentális utóhatások jelentős része feltételezhetően az egyéb prediszpozícióknak tulajdonítható: a nehéz életkörülményeknek, családon belüli erőszaknak, már fennálló mentális betegségeknek, amelyek a nem várt terhesség megtörténtéhez is hozzájárulhatnak (Steinberg - Rubin 2014). A szükségszerűként láttatott negatív következmények hangsúlyozása akár az áldozathibáztatásnak is teret adhat, hiszen, ha egy nő már élt a teste feletti való döntés jogával (ráadásul egy morális szempontból megkérdőjelezhető módon, a terhessége szándékos megszakíttatásával), akkor az abortusz után felmerülő bármilyen negatív következményért is csak ő lehet felelős. A testi önrendelkezés, autonómia hangsúlyozása - elvi szinten legalábbis - nagy mértékü ágenciával ruházza fel az abortusz választása előtt álló nőket, míg a „senkinek semmi köze hozzá" érvelés elvitatja azt, hogy más szereplők is érintettek lehetnek, így felelősségük is lehet a terhesség megszakításában, vagyis a döntés joga és egyben felelőssége is kizárólag a nőé.

Ráadásul ez a retorika, az abortusz-döntés kényszerhelyzetben hozott, rossz, de szükségszerű választásként való keretezése épp az alternatívák közti szabad választás (és ilyen értelemben az önrendelkezés) jogát vitatja el a nőktől. 


\section{KÖZELKÉP - Tanulmányok}

Az abortusz krízisként való megélése, ennek az élményvilágnak a felülreprezentálása háttérbe szorítja a nők egyéb abortuszélményeit, amely ennél sokkal semlegesebb, vagy akár pozitívabb lehet a valóságban (Beynon - Jones 2017, Purcell et al. 2014, Steinberg - Jordan - Wells 2009).

Hasonlóan befolyásolhatja az abortuszt választó nőkről való elképzeléseket az, hogy a média milyen szereplőkkel jeleníti meg az adott kérdést. Az elemzett cikkekben a megszólaltatott, és egyedi történeteiket elmesélő nők fiatal (18 év alatti vagy annál alig idősebb) lányok, akik vagy életkoruk vagy aktuális élethelyzetük (pl. egyetemi tanulmányok) miatt nem vállalják a magzat kihordását. Bár igaz, hogy hazánkban az abortuszgyakoriságok maximuma egyre fiatalabb korra tolódik (a korábbi évekhez hasonlóan 2018-ban is a huszonéves nőknél volt a leggyakoribb a múvi vetélés; KSH 2019), a fiatal életkor ilyen mértékű felülreprezentálása, és mellette az idősebb, már családdal rendelkezo, gyermekes nők említésének szinte teljes hiánya disztorzív képet alakít ki az abortuszt választó nőkről, és egyben a döntés okairól is. Az éretlenség és a jövőbeli lehetőségek szem előtt tartása mellett a párkapcsolati problémák, anyagi nehézségek vagy a már befejezettnek tekintett családtervezés egyáltalán nem ábrázolódnak, holott ezek a valóságban gyakoribb, vagy nagyságrendileg hasonló gyakoriságú okok, mint az, hogy az érintett nő hajadon vagy tanul (Turay - Horváth - Kovács - Kneffel 1997). Hasonlóan felülreprezentált a bemutatott történetekben a nemi erőszak során megfogant terhességek művi megszakítása (miközben az erőszak következtében létrejött terhességek elvetetésének aránya hazánkban 0,1\%; KSH 2007), tovább hangsúlyozva azt, hogy az abortusz választása csak ilyen (az átlagostól eltérő) helyzetekben igazolható. A terhességmegszakítás melletti döntés sem demográfiai, sem az okok vonatkozásában nem reprezentatív, homogenizáló ábrázolása nem teszi lehetővé az abortuszhoz társuló különféle érzelmi tapasztalatok bemutatását (Beynon - Jones 2017), és fokozhatja azoknak a nőknek az elszigeteltségérzését, akik más életkori csoportba tartoznak, más okból döntöttek a terhességük megszakítása mellett és/vagy azzal kapcsolatban más tapasztalatokkal bírnak.

Ráadásul a terhességmegszakítás konzekvens összekapcsolása a megbánással és/vagy a mentális és fizikai ártalmakkal, az abortuszt választó nők sztereotipizáló, élményeiket homogenizáló ábrázolása, csakúgy mint kizárólagos felelősségük hangsúlyozása utat nyit az abortusz, illetve a művi vetélés mellett döntő nők stigmatizálásának is (Purcell et al. 2014).

A szövegekben a terhességmegszakítás gyakran azzal normalizálható, ha olyan élethelyzetekkel állítják azt párhuzamba, amelyek szintén negatív (vagy még negatívabb) konzekvenciákkal járnak. Ilyen lehet az illegális abortuszok körülményeinek és következményeinek érzékletes taglalása, valamint a kényszerből vállalt anyaság boldogtalan állapotként, és a gyerekre is terheket rakó, későbbi sorsát determináló kimenetként történő bemutatása is. Utóbbi az a helyzet, amelyben az anyaság nem 


\section{KÖZELKÉP - Tanulmányok}

pozitív keretben jelenik meg, szemben azzal az - elemzett cikkek által is közvetített - elképzeléssel, hogy a gyermekvállalás az egyedül érvényes döntés, amit minden nő választana ideális körülmények között. Ennek megfelelően a művi abortusz explicit vagy implicit módon - az anyaság elutasításaként értelmeződik (ami szemantikailag is alátámasztott: ha a várandós nő „anya”, akkor a terhesség megszakítása eleve az anyaság elleni cselekvés). Egyedül a fiatal életkor az, ami felmentést ad ez alól: ha az anyaság vágya még (érthetően) nem jelenik meg, a magzat elvetetése nem válik összeegyeztethetetlenné az anyai szerepvállalással.

A kutatás további kérdése volt, hogy melyek azok a tartalmi elemek, amelyek nem képezik az abortuszról szóló diskurzus részét. Ilyen volt a terhességmegszakítással összefüggő semlegesebb, vagy akár pozitív élmények és attitűdök már említett hiánya. (A neutrális, nem drámaiként, vívódásként megélt abortuszélmény csak a háborús idők extrém körülményei között lehet érvényes.) A másik hiányzó elem a férfiak és/vagy párkapcsolat. Az abortusszal kapcsolatos férfi érintettség jellemzően közvetetten jelenik meg, úgy, hogy az abortuszhoz való jogot nem a nők szabadságjogaként, hanem alapvető emberi jogként említik. A férfiak kapcsán inkább a témában való illetékességük elvitatása kap hangsúlyt: jellemző az az érvelés, hogy mivel a férfiak nem tudnak szülni, ne szóljanak bele az abortusszal kapcsolatos kérdésekbe sem, és csak elvétve említik meg a férfiak felelősségét a nem kívánt terhesség létrejöttében. A terhességre vonatkozó döntésnek kizárólag női kérdésként való tematizálása, a férfiak diszkurzív kizárási szándéka azonban gátja lehet annak, hogy vizsgáljuk a férfiak szerepvállalását, felelősségét nem csak a művi abortusszal, de a nem kívánt terhességgel és a fogamzásszabályozással kapcsolatban is. A férfiak vagy egyházi személyként, politikusként, orvosként vagy nőket megerőszakoló férfiként szerepelnek a szövegekben, de legritkább esetben vannak jelen apaként vagy a megfogant magzatért felelős férfiként.

A kutatás limitációi közé tartozik, hogy a szövegeket célzottan egy központi témára (lengyel abortusztörvény) szúkítetten válogattuk, amely befolyásolhatta a művi abortusz megjelenítését a szövegekben. Mivel maga a helyzet, a taglalt események társadalmi kontextusa eleve konfliktuózus volt, ez hathatott a nyelvi ábrázolás módjára is. Ezt figyelembe véve további kutatás tárgyát képezheti a terhességmegszakítással kapcsolatos, ám az adott történelmi-társadalmi környezettől függetlenebb médiatartalmak elemzése. A vizsgálatba bevont szövegek más, elsősorban nyelvi elemzése is fontos információkkal szolgálhatna a téma kapcsán, mi erre nem, vagy csak részlegesen tértünk ki. 


\section{KÖZELKÉP - Tanulmányok}

\section{Irodalom}

American Psychological Assosiation Task Force on Mental Health and Abortion (2008): Report of the task force on mental health and abortion. Letöltve: 2017. 10. 01. http://www.apa.org/pi/women/programs/abortion/mental-health.pdf

Baird, B. (2001): Abortion, questions, ethics, embodiment. History Workshop Journal, 52: 197-216.

Beauvais, E. - Mann, E. - Lore, G. (2016): Continental Gender Divide: Abortion Attitudes in the United States and Canada. Letöltve: 2017. 10.11. https://cpsa-acsp.ca/documents/conference/2016/Beauvais-Mann-Lore.pdf

Beynon-Jones, S. M. (2017): Untroubling abortion: A discourse analysis of women's accounts. Feminism \& Psychology, 27(2): 225-242.

Bowman, K. - Marsico, J. (2014): Attitudes about abortion. AEI Public Opinion Studies, Letöltve: 2018.02.06. https://www.scribd.com/document/200228748/ Attitudes-about-abortion

Braun, V. - Clarke, V. (2006): Using thematic analysis in psychology. Qualitative Research in Psychology, 3(2): 77-101.

Calhoun, C. - Karaganis, J. (2001): Critical theory. In: G. Ritzer - B. Smart (eds.): Handbook of social theory (179-200). London, Sage Publications.

de Crespigny, L. J. - Wilkinson, D. J. - Douglas, T. - Textor, M. - Savulescu, J. (2010): Australian attitudes to early and late abortion. The Medical Journal of Australia, 193(1): 9-12.

Dudová, R. (2010): The Framing of Abortion in the Czech Republic: How the Continuity of Discourse Prevents Institutional Change. Sociologický Časopis/ Czech Sociological Review, 46(6): 945-975.

Furedi, A. (2001): Issues for service providers: a response to points raised. Journal of medical ethics, 27(suppl 2): 28-32.

Ganatra, B. - Gerdts, C. - Rossier, C. - Johnson Jr, B. R. - Tunçalp, Ö. - Assifi, A. et al. (2017): Global, regional, and subregional classification of abortions by safety, 2010-14: estimates from a Bayesian hierarchical model. The Lancet, 390(10110): 2372-2381.

Glózer R. (2007): Diszkurzív módszerek. In: Kovács É. (szerk.): Közösségtanulmány: módszertani jegyzet (260-267). Budapest, Néprajzi Múzeum, PTE BTK Kommunikáció- és Médiatudomány Tanszék.

Hill, C. E. - Thompson, B. J. - Williams, E. N. (1997): Aguide to conducting consensual qualitative research. The Counseling Psychologist, 25: 517-572.

Hohmann, S. A. - Lefèvre, C. A. - Garenne, M. L. (2014): A framework for analyzing sex-selective abortion: the example of changing sex ratios in Southern Caucasus. International Journal of Women's Health, 6: 889-897. 


\section{KÖZELKÉP - Tanulmányok}

Jozkowski, K. N. - Crawford, B. L. - Hunt, M. E. (2018): Complexity in Attitudes Toward Abortion Access: Results from Two Studies. Sexuality Research and Social Policy, 15(4): 464-482.

Központi Statisztikai Hivatal (2007): Terhességmegszakítások 1995-2006. Letöltve: 2018.02.06.

http://www.ksh.hu/pls/ksh/docs/hun/xftp/idoszaki/pdf/terhesmegsz06.pdf

Központi Statisztikai Hivatal (2019): Magyarország, 2018. Letöltve: 2019. 10. 20. https://www.ksh.hu/docs/hun/xftp/idoszaki/mo/mo2018.pdf

Marecek, J. - Macleod, C. - Hoggart, L. (2017): Abortion in legal, social, and healthcare contexts. Feminism \& Psychology, 27(1): 4-14.

Meyer, M. (2001): Between Theory, Method and Politics: Positioning of the Approaches to Cda. In: Wodak, R. - Meyer, M. (eds.): Methods of Critical Discourse Analysis. London, Sage Publications, 14-21.

Mikołajczak, M. - Bilewicz, M. (2014): Foetus or child? Abortion discourse and attributions of humanness. British Journal of Social Psychology, 54(3): 500-518.

Miles, M. B. - Huberman, A. M. (1984): Qualitative data analysis: A sourcebook of new methods. London: Sage Publications.

Norris, A. - Bessett, D. - Steinberg, J. R. - Kavanaugh, M. L. - De Zordo, S. - Becker, D. (2011): Abortion stigma: a reconceptualization of constituents, causes, and consequences. Women's Health Issues: Official Publication of the Jacobs Institute of Women's Health, 21(3 Suppl): 49-54.

Papworth, V. (2011): Abortion services: the need to include men in care provision. Nursing Standard, 25(40): 35-37.

Parsons, N. K. - Richards, H. C. - Kanter, G. D. (1990): Validation of a scale to measure reasoning about abortion. Journal of Counseling Psychology, 37(1): 107-112.

Purcell, C. - Hilton, S. - McDaid, L. (2014): The stigmatisation of abortion: a qualitative analysis of print media in Great Britain in 2010. Culture, Health \& Sexuality, 16(9): 1141-1155.

Seale, C. (2003): Health and media: an overview. Sociology of Health \& Illness, 25(6): 513-531.

Sedgh, G. - Singh, S. - Shah, I. H. - Åhman, E. - Henshaw, S. K. - Bankole, A. (2012): Induced abortion: incidence and trends worldwide from 1995 to 2008. The Lancet, 379(9816): 625-632.

Sedgh, G. - Bearak, J. - Singh, S. - Bankole, A. - Popinchalk, A. - Ganatra, B. et al. (2016): Abortion incidence between 1990 and 2014: global, regional, and subregional levels and trends. The Lancet, 388(10041): 258-267. 


\section{KÖZELKÉP - Tanulmányok}

Sisson, G. - Kimport, K. (2014): Telling stories about abortion: abortion-related plots in American film and television, 1916-2013. Contraception, 89(5): 413-418.

Sisson, G. - Rowland, B. (2017): „I was close to death!”: abortion and medical risk on American television, 2005-2016. Contraception, 96(1): 25-29.

Steinberg, J. R. - Jordan, B. - Wells, E. S. (2009): Science prevails: abortion and mental health. Contraception, 79(2): 81-83.

Steinberg, J. R. - Rubin, L. R. (2014): Psychological Aspects of Contraception, Unintended Pregnancy, and Abortion. Policy Insights from the Behavioral and Brain Sciences, 1(1): 239-247.

Takács E. (2015a): A születés esetlegességei. A prenatális diagnosztika szociológiai problematizálása. In: Kisdi B. (szerk.): Létkérdések a születés körül. Budapest, L’Harmattan Kiadó, Könyvpont Kiadó, 395-411.

Takács E. (2015b): Fogamzás és terhességmegszakítás: Magzat-irodalom a kortárs francia szociológiában. socio.hu, 5(1): 105-121.

Tollefsen, C. (2015): Pope Francis and Abortion. Christian Bioethics: Non-Ecumenical Studies in Medical Morality, 21(1): 56-68.

Turay A. - Horváth B. - Kovács L. - Kneffel P. (1997): Terhességmegszakítás és párkapcsolat. Magyar Nőorvosok Lapja, 60(3): 227-230.

Uldall, S. W. (2015): How Danes evaluate moral claims related to abortion: a questionnaire survey. Journal of Medical Ethics, 41(7): 570-572.

Woodruff, K. (2019): Coverage of Abortion in Select US Newspapers. Women's Health Issues, 29(1): 80-86.

World Health Organization (2012): Safe abortion: technical and policy guidance for health systems. Geneva, Switzerland: World Health Organisation. Letöltve: 2018. 02. 06. http://www.who.int/reproductivehealth/publications/unsafe_abortion/ 9789241548434/en/ 